\title{
Evaluation of the Anti-nutritional Substances in the Fruit of Gleditsia triacanthos L.: Economic Interest and Perspectives of Valorization in Algeria
}

\author{
Samia Benhamiche, Hachemi Benhassaini and Kheira Chabane \\ Department of Environmental Sciences, Laboratory of Vegetal Biodiversity Conservation \& Valorization, University Djillali Liabes \\ of Sidi Bel Abbes, Sidi Bel Abbes 22.000, Algeria
}

\begin{abstract}
Honey locust (Gleditsia triacanthos L.), also called sweet-locust or thorny-locust, is a moderately fast growing tree. It is widely planted for windbreaks and soil erosion control and largely recommended like food of cattle since it can provide a source of fodder, protein and metabolic energy. Its flowers are incredibly attractive for pollinating insects and thus, form a source of pollen and nectar for honey. This tree was introduced in Europe in 1700 and was introduced by the colonists into Algeria in 1949. In order to valorize the natural substances of this species, the evaluation of the composition of its fruits (pods and seeds separately) in polyphenols, condensed tannins and hydrolysable tannins, which considered as anti-nutritional substances has been done. The obtained results showed that the fruits of Gleditsia triacanthos L. contain very low values in anti-nutritional factors with $(0.13 \%-0.03 \%)$ of condensed tannins, $(0.78 \%-0.45 \%)$ of hydrolysable tannins and $(0.44 \%-0.16 \%)$ of total phenols for pods and seeds, respectively. It arises that these fruits can be of a great interest for many industries especially for feedstock.
\end{abstract}

Key words: Gleditsia triacanthos L., anti-nutritional substances, pods and seeds, valorization.

\section{Introduction}

Honey locust (Gleditsia triacanthos L.) is a leguminous tree, native to North America that grows up to $20 \mathrm{~m}$ high. It has been widely planted throughout the world (Africa, Australia and South America) for various purposes, including windbreaks, shelterbelts, erosion control, wildlife food and local wood products $[1,2]$.

This species is drought resistant, light lover, thorny and show moderate to fast growth speed [3]. It is considered by numerous authors [4] as common invader, although it can be competitive for the native species and form an ecologic danger. Its seeds are composed of the testa (27\%), the embryo (29\%) and the endosperm (34\%) [5].

The pods are edible and can be used as vegetable or fermented to produce alcoholic or non-alcoholic

Corresponding author: Samia Benhamiche, Ph.D., main research field: vegetal biodiversity. beverage. Pods and foliage are valuable fodder for all classes of livestock [6]. The honey locust tree flowers are attractive sources of nectar for bees and thus, good honey source. The trunk, pods and bark are also used in many ethno-medicines [6].

In Algeria, no study has treated this kind of analysis on Gleditsia triacanthos L. fruits. The aim of this work is to define the composition of Gleditsia triacanthos L. fruits on polyphenols, condensed tannins and hydrolysable tannins which considered as anti-nutritional substances.

\section{Material and Methods}

The pods of Gleditsia triacanthos L. were collected from the University of Djillali Liabes (ITMA) Sidi Bel Abbes (altitude: $486 \mathrm{~m}$, latitude: $35^{\circ} 11^{\prime} \mathrm{N}$, Longitude: $00^{\circ} 38^{\prime} \mathrm{W}$ ) during November 2014 (Fig. 1). The pods were dried in the shade during 3 months. The seeds were separated manually, then crushed separately. The resulting flour was preserved in glass bottles, safe from 

and Perspectives of Valorization in Algeria

the light for further use.

Polyphenols was determined using Bate Smith method [7]. The first step was a methanolic extraction: using $0.2 \mathrm{~g}$ of milled powder (seeds and pods separately). After that, many reagents has been used $\left(\mathrm{FeCl}_{3}\right.$ at 0.1 molar in $\mathrm{HCL} 0.1$ normal (volume/volume)) and $\left.\mathrm{K}_{3} \mathrm{Fe}(\mathrm{CN})_{6}\right)$. The absorbance was read at $\lambda=725$ manometer. The polyphenols were determined by Eq. (1):

$$
T=A \times \frac{V \times D}{P S}
$$

Where, T: total phenols, V: volume of used extract, D: dilution factor, A: absorbance and Ps: sample weight.

Condensed tannin of dried pods and seeds was determined by vanillin/ $\mathrm{H}_{2} \mathrm{SO}_{4}$ method [8]. An amount of $0.2 \mathrm{~g}$ of milled powder was macerated for 18 hours in $10 \mathrm{~mL}$ of $80 \%$ methanol. One $\mathrm{mL}$ of filtrate was added to $2 \mathrm{~mL}$ of a solution prepared with $1 \%$ vanillin in $70 \%$ sulfuric acid. The entire mixture was placed in a water bath for $15 \mathrm{~min}$ at $20{ }^{\circ} \mathrm{C}$ protected from light. The absorbance was read at $500 \mathrm{~nm}$. The condensed tannin levels were determined by Eq. (2):

$$
T C(\%)=\left(5.2 \times 10^{-2} \times D O \times V\right) / P
$$

Where, TC: condensed tannins, $5.2 \times 10^{-2}$ constant expressed in equivalent cyanidins, DO: absorbance, $\mathrm{V}$ : volume of the used extract and P: sample weight.

Hydrolysable tannins of dried pods and seeds were determined using Bate-Smith method [7]. An amount of $0.2 \mathrm{~g}$ of milled powder was macerated for 18 hours in $10 \mathrm{~mL}$ of $80 \%$ methanol. One $\mathrm{mL}$ of the filtrate was added to $3.5 \mathrm{~mL}$ of a solution prepared with ferric trichloride $\left(\mathrm{FeCl}_{3}\right)$ at 0.01 molar in hydrochloric acid (HCl) at 0.001 molar. After 15 seconds, the absorbance of the mixture was read at $660 \mathrm{~nm}$. The rate of hydrolysable tannins was determined by Eq. (3):

$$
T H(\%)=D O \times M \times V / E \text { Mole } \times P
$$

Where, TH: Hydrolysable Tannins, DO: absorbance, E Mole: 2.169, gallic acid (constant expressed in moles), $\mathrm{M}$ : mass $=300, \mathrm{~V}$ : volume of the extract used and P: weight of sample. The results are converted into milligrams by a gram of dry matter.

The results were expressed as mean \pm standard deviation ( $\mathrm{SD}, \mathrm{n}=3$ ). SPSS software (version 19.0) was used for the statistical analysis.

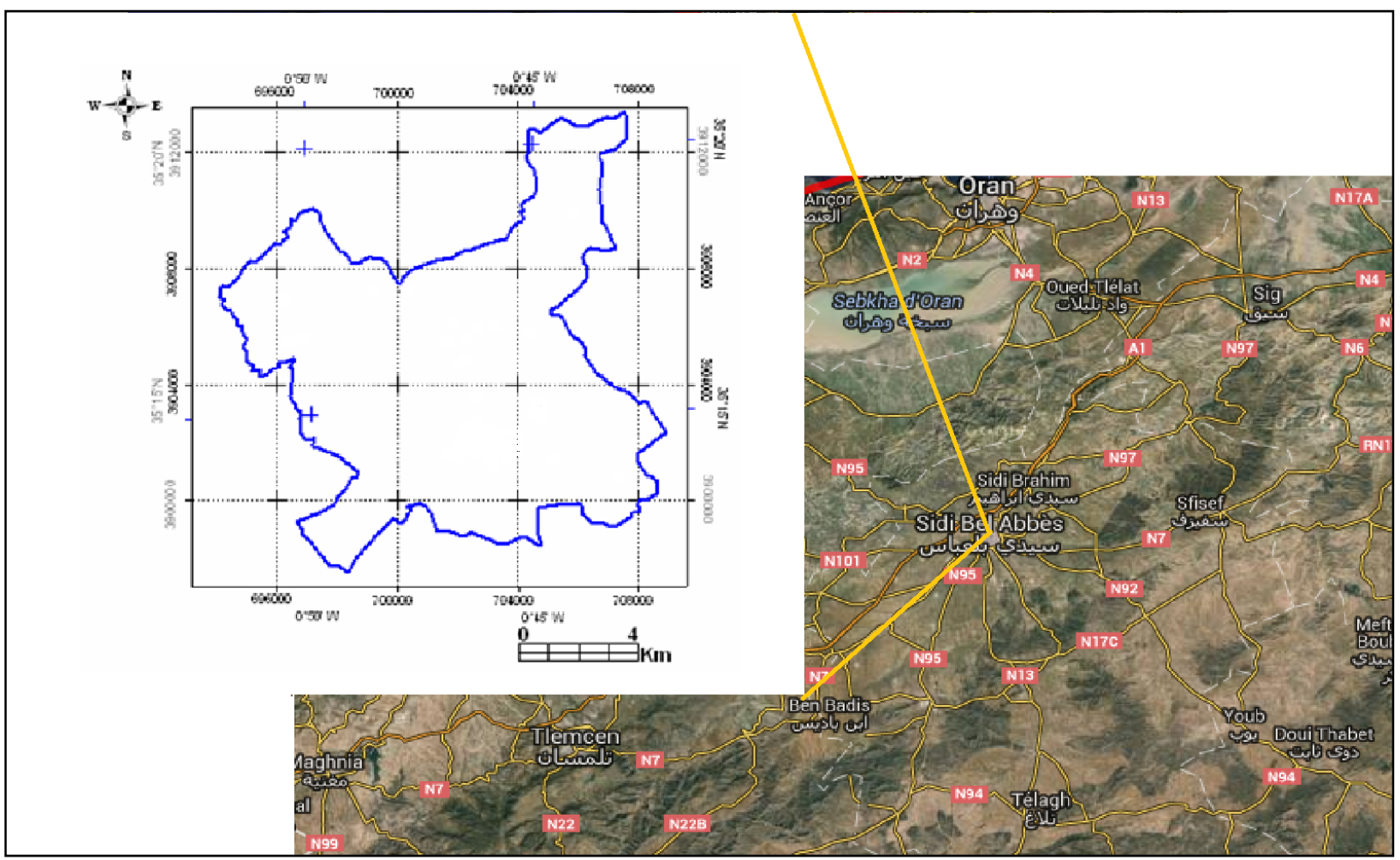

Fig. 1 Geographic location of Sidi Bel Abbes (Algeria). 


\section{Evaluation of the Anti-nutritional Substances in the Fruit of Gleditsia triacanthos L.: Economic Interest 221 and Perspectives of Valorization in Algeria}

\section{Results and Discussion}

Honey locust (Gleditsia triacanthos L.), well known as an ornamental tree has been widely advocated as a livestock feed in the early 20th century. The development of sylvopastoral cultivars began in 1930 at the Tennessee valley (United States), because they can provide a source of fodder, protein and metabolic energy [9]. The majority of the works were interested to the biochemical composition of the gum extracted from the seeds of Gleditsia triacanthos L. [5] and to the characterization of the galactomannans extracted from this gum often used in food industry, as well as their rheological properties [10]. For this case, it was very interesting to evaluate the anti-nutritional substances composition.

As shown in Table 1, total phenols are present in seeds and pods of Gleditsia with low percentages $(0.44 \%$ and $0.16 \%$, respectively). According to Miguel, A. et al. [11], phenolic compounds extract from Gleditsia triacanthos L. are very hydrolysable and can be used as a natural source of phenolic compounds and antioxidants.

The tannins are considerate as anti-nutritional compounds. They have phenolic forms able to bind to proteins in solution and precipitate them. Two great groups of tannins can be distinguishing. They are different at the same time by their chemical reactivity and their compositions: condensed tannins and hydrolysable tannins [12]. They have a considerable economic and ecological importance and are responsible for astringency of many fruits and vegetables [13]. According to the international alimentary code (CODEX Alimentarius) [14], the content of tannins in whole grains should not exceed $0.5 \%$ on the basis of dry matter. The results are according to the norms, with very low rates of condensed and hydrolysable tannins $(0.033 \%-0.45 \%$ in seeds and $0.13 \%-0.78 \%$ in pods, respectively). Other results $[15,16]$ on Gleditsia triacanthos L. tannin compounds reveal a very high percentage compared to those found in the present study.
Table 1 Composition on Anti-nutritional substances of Gleditsia triacanthos L. fruits.

\begin{tabular}{lll}
\hline $\begin{array}{l}\text { Gleditsia triacanthos Pods }(\mathrm{M} \pm \mathrm{SD}) \\
\text { L. }\end{array}$ & $\begin{array}{l}\text { Seeds }(\mathrm{M} \pm \mathrm{SD}) \\
(\%)\end{array}$ \\
\hline Polyphenols & $0.16 \pm 0.06$ & $0.44 \pm 0.001$ \\
Condensed tannins & $0.13 \pm 0.001$ & $0.03 \pm 0.007$ \\
Hydrolysable tannins & $0.78 \pm 0.38$ & $0.45 \pm 0.14$ \\
\hline
\end{tabular}

* M: mean and SD: standard deviation.

This difference can be explained by the difference in ecological factors, geographic situation and species variety. However, the different methods and protocols of analysis used imply a careful comparison of the values.

Moderate levels of tannins (less than 4\%) in forage legumes can have beneficial responses in ruminants, resulting in higher growth rates and milk yield. However, even in ruminants, levels of tannins exceeding $6 \%$ of the diet result in negatively affect growth rates and milk yield [17].

As first observation, it can be consider that the fruits of honey locust collected in the region of Sidi Bel Abbes (semi-arid climate) represent a great interest for the production of feedstock, since they contain very low rates of anti-nutritional substances which can contribute to reduce the invoice of cattle food importation.

\section{Conclusions}

At the light of these results, a future prospective can be opened for the use of the fruits of honey locust (Gleditsia triacanthos L.) as a source of energy which can be used in many industrial and pharmaceutical fields especially in the production of livestock food and attribute to reduce the exorbitant invoice.

\section{References}

[1] Blair, R. M. 1990. "Gleditsia triacanthos L. Honey Locust." In Hardwoods Agriculture Handbook, edited by Burns, R. M., and Honkala, B. H. Washington DC: USDA Forest Service.

[2] Ürgenç, S. 1998. "General Plantation and Afforestation Techniques." Doctor thesis. Istanbul University.

[3] Burner, D. M., Pote, H., and Ares, A. 2005. "Management Effects on Biomass and Foliar Nutritive 

and Perspectives of Valorization in Algeria

Value of Robinia pseudo acacia and Gleditsia triacanthos in Arkansas, USA." Agroforestry Systems 65: 207-214.

[4] Ghersa, C. M., De La Fuente, E., Suarez, S., and Leon, R. J. 2002. "Woody Species Invasion in the Rolling Pampa Grasslands, Argentina." Agriculture Ecosystem and Environment 88: 271-278.

[5] Sciarini, L. S., Maldonado, F., Ribotta, P. D., Pérez, G. T., and León, A. E. 2009. "Chemical Composition and Functional Properties of Gleditsia triacanthos Gum." Food Hydrocolloids 23: 306-13.

[6] Orwa, C., Mutua, A., Kindt, R., Jamnadass, R., and Anthony, S. 2009. "Honey Locust (Gleditsia triacanthos)." Accessed June 10, 2013. http://www.worldagroforestry.org/resources/databases/ag roforestree.

[7] Bate Smith, E. C. 1973. "A Haemanalysis of Tanins: The Concept of Relative Astringency." Phytochemistry 12: 907-12.

[8] Price, M. L., and Bulter, L. G. 1977. "Rapid Visual Estimation and Spectrophotometric Determination of Tannin Content of Sorghum Grain." Agriculture and Food Chemistry 25: 1268-1273.

[9] Gold, M. A. 1997. Gleditsia Triacanthos-honey Locust, Widely Adapted Temperate Zone Fodder Tree. Morrilton: FACT Sheet, Winrock International.

[10] Bourbon, A. I., Pinheiro, A. C., Ribeiro, C., Miranda, C., Maia J. M., and Teixeira, J. A. 2010. "Characterization of Galactomannans Extracted from Seeds of Gleditsia triacanthos and Sophora japonica through Shear and Extensional Rheology: Comparison with Guar Gum and Locust Bean Gum." Food Hydrocolloids 24 (2-3): 184-92.

[11] Miguel, A., Cerqueira, M. A., Bartolomeu, W. S., Souza, Joana, T., Martins, José, A., and Teixeira, António, A. 2010. "Seed Extracts of Gleditsia triacanthos: Functional Properties Evaluation and Incorporation into Galactomannan Films." Food Research International 43: 2031-38.

[12] Manchando, P. S., Macheix, A., and Fleuriet, J. J. 2006. Polyphenols in Agro-alimentary. Paris: Lavoisier.

[13] Kumar, R., and Singh, M. 1984. "Tannins: Their Adverse Role in Ruminant Nutrition." Agriculture Food Chemistry 32: 447-53.

[14] Codex Alimentarius, ALINORM 95/29. 1995. Alimentary Mixed FAO/OMS Program for Norms. Roma: Codex Alimentarius Commision.

[15] Bruno-Soares, A. M., and Abreu, J. M. 2003. "Merit of Gleditsia triacanthos Pods in Animal Feeding Chemical Composition and Nutritional Evaluation." Feed Science and Technology 107: 151-60.

[16] Kamalak, A., Guven, I., Kaplan, M., Boga, M., Atalay, A. I. and Ozkan, C. O. 2012. "Potential Nutritive Value of Honey Locust (Gleditsia triacanthos) Pods from Different Growing Sites for Ruminants." Agriculture Sciences and Technology 14: 115-26.

[17] Van Soest, P. J. 1994. Nutritional Ecology of the Ruminants (2nd Ed.). USA: Cornell University Press. 